This is an electronic reprint of the original article. This reprint may differ from the original in pagination and typographic detail.

Author(s): Kumpulainen, Kaisu

Title: $\quad$ The discursive construction of an active rural community

Year: $\quad 2017$

Version:

Please cite the original version:

Kumpulainen, K. (2017). The discursive construction of an active rural community.

Community Development Journal, 52(4), 611-627.

https://doi.org/10.1093/cdj/bsw009

All material supplied via JYX is protected by copyright and other intellectual property rights, and duplication or sale of all or part of any of the repository collections is not permitted, except that material may be duplicated by you for your research use or educational purposes in electronic or print form. You must obtain permission for any other use. Electronic or print copies may not be offered, whether for sale or otherwise to anyone who is not an authorised user. 
Kaisu Kumpulainen

kaisu.kumpulainen@jyu.fi

\section{The discursive construction of an active rural community}

In this article, I will study active rural communities, how they are constructed in the speech of local people involved in community development practices. Over the past twenty years, community-led development practices have been a new paradigm for the rural development in Finland, which has been reflected as increasing number of village associations. I will analyse the discursive construction of the active community by interviewing all the present and previous leaders of three active village associations in the province of Central Finland. Active rural communities are constructed through village associations, by their local activities and self-consciousness as active communities. In the local representations, a rural community is constructed especially as a nurtured process, which progresses and develops according to the amount of local people's commitment to the home village. Even if the leaders of active communities have adopted the strategic development discourse as the way to define their villages, the rural policy objective to get rural communities to adopt entrepreneurial subjectivity has not been achieved. Instead, the local discourse reflects how the local activeness is more about struggling for survival. Despite the contradiction between rural policy and local level, the activeness discourse constructs village associations as responsible for keeping villages alive through the rationality and practices of rural community development.

\section{Introduction}

Over the past twenty years, bottom-up approaches, community-led development and participation have been popular instruments in diverse policy circles (Eversole, 2010, p. 30). Community-based development practices have also been seen as a new paradigm for rural development in European Union (Ray, 2000) and in OECD countries (Krawchenko, 2014). In Finland, the village associations are the most significant actors in adopting the community development approach in rural areas (Kumpulainen, 2012). The village action movement started in Finland already in the 1970s, but in 1990s it was integrated as a part of national and European Union rural policy strategies and networks (Hyyryläinen, 2000). It was reflected as the establishment of national village action programmes, increased development project funding and more strategic development work in the local level. 
In 2013, there were 3074 village associations in Finland, covering most of the villages in the country (there are about 4235 villages in Finland). Village associations, for example, maintain and renovate community halls, organize events and recreation activities, take care of important outdoor activity sites and communicate with the city officials on behalf of the villagers. They do not have any permanent financial support from the state or from the municipality; the incomes come through associations' own fund raising and from European Union project funding. Village action is not a discrete rural phenomenon, but a part of the wider change of governmentality related to active citizenship politics (Kearns, 1992; Gaynor, 2011). Ever since 1980s, community involvement has been commonly adopted all around Western societies as a part of active citizenship politics and an efficient practice to increase welfare in different policy circles (Kearns, 1995; Marinetto, 2003). Active citizenship means that there is an object to make individual citizens more responsible for their own welfare by reconstructing citizens as members of active communities (Rose, 2000). In rural context, activating citizens takes place through village associations which are encouraged to take more responsibility of the development of rural areas.

Since 1990s, also Finland has been moving towards neoliberal policy, and active citizenship politics has been one instance of where the role of strong welfare state has been questioned. In addition to the community-led development practices, the emphasis in Finnish social policy has also been, from the mid-1990s onward, on activating individual citizens and communities (Kotkas, 2010, p. 165). The encouragement of village associations to activate themselves and to produce local welfare not only means seeking solutions to local rural problems but it is also a part of the broader rationality of governing, where responsibilities are transferred from the public sector to individuals and communities (Herbert-Cheshire and Higgins, 2004; Blakeley, 2010).

In this article, I study the construction of active rural communities, how they are represented in the speech of active village association leaders. In Finnish rural policy, there is an explicit objective to promote active citizenship in rural areas through village action. My main research questions are: Have the local active communities adopted the active subjectivity offered them in rural policy? Are there any contradictions between the policy level and the local level in the representations of an active community? I have collected the data by interviewing the chairmen of active village associations (twelve interviews) in the province of Central Finland. Since I am interested in the social representations of activeness, the village associations and the interviewees for the study are chosen from the local actors who are the most active ones in their own communities and who also activate other people to get involved in community development practices.

\section{Village action promoting active citizenship}


In Finland, the neoliberal politics has influenced different sectors of the society, and in rural areas this has manifested as the increasing role of local communities in their own development. Village action means a more strategic approach in organizing community activities and it changes the character of rural communities according to the objectives of active citizenship. The development practices in villages are not only new means of organizing local activities but also an effective means of social regulation connected to the wider ideological and political circles in the society (Marinetto 2003).

The broad definition of governing (Foucault, 2002) offers a useful theoretical approach when interpreting the connections between local community level and policy level processes. Governing citizens is based on how people are constituted and how they constitute themselves as moral subjects (Foucault, 1981; Rabinow, 1991; Dean, 1999, p. 67-79; Marinetto, 2003). According to Cruikshank (1996), empowerment and community involvement are particular technologies of citizens in liberal democracy constructing a certain kind of subjectivity that is less dependent on the state Cruikshank, 1996; Marinetto, 2003). Participation and community development practices can be seen as self-technologies constructing responsible citizens in rural areas (Triantafillou and Nielsen, 2001). In Finnish villages, being a moral subject consists of being active in the local village association and getting involved in community development practices in the home village.

Active citizenship is a part of politics purporting to find solutions to societal problems by emphasizing the role of communities (Gaynor, 2011; Rose, 2000). Rose (1999) describes governing through community as a particular practice, where the self-governing of active citizens becomes apparent. Marinetto (2003), in turn, depicts active citizenship as a strategy where the governing is based on the relationship between civil society and the state. Active citizenship politics has increased the responsibilities of local communities in providing welfare for citizens and the civil society actors, and NGOs are expected to fill the gaps in the welfare society (Kearns, 1992; Rose, 2000). In Finland, the state encourages rural communities to take responsibility in promoting welfare in rural areas. There is a clear statement in rural policy and in national village action programmes of the growing role of village associations in developing and producing local services and livelihood, which means relocating the responsibility of state and municipalities to self-governing local communities (Kumpulainen, 2012).

The Village Action Association of Finland was established in 1997 as a part of the process to integrate the village action movement into Finnish rural policy, and it was reflected as a more strategic approach to rural community development. In its official definition, the Finnish rural policy does not recognize a village if it does not have its own village association (Kumpulainen, 2012, p. 37). It is a strong 
statement by the government that rural communities should be based on development work implemented by NGOs. The national village action association has established four national rural community development programmes since the year 2000, and they are in accordance with the national rural policy programmes. In these programmes, the association defines the general objectives and principles for rural community development in Finland.

In the national village action discourse, there is a clear statement that 'Village action is one instrument to educate active citizenship' (p. 47, the second Finnish village action programme, 2003-2007). According to the programmes, villages have to take more societal responsibility in rural areas.

In this situation, it is worth considering, how a village is organized to take responsibility. It is quite possible that a village association takes responsibility for expanding and manifold tasks concerning the village. The future is more and more about the associations who take responsibility. (p. 8, the third village action programme, 2008-2013)

A lot of promises are given, in the programmes, about how rural communities should help the society, for example, by taking responsibility of the local security and of the elderly people. The promises are ambitious and even exaggerated. Even if not fully realistic, the objectives are a part of politics that negotiate the roles of state and civil society in a new way (Kearns, 1995). Finnish rural community development is one arena where the state is withdrawing and thus trying to increase the communities' own responsibility in providing local welfare.

In active citizenship politics, communities are seen as the moral and emotional texture that keeps its members together (Rose, 1999, p. 172-173).

Moral responsibility is framed as the identity, values and belongingness to the community (Rose, 2000). The communities constructed by local development practices are also often seen as mythical, natural and unquestioned (Williams, 2004, p. 561-564). Village associations are a paradigmatic example of communities that are actively constructed through development practices: their existence is not a natural process but demands constant strategic development work. Nevertheless, they are based on the moral and emotional bond of people to a certain place - to a village. The moral bond can be activated and mobilized through different programmes and techniques in accordance with prevailing governmental rationality (Rose, 1999). Rose defines this kind of politics as ethopolitics where ethopower works through people's values and obligations to others (Rose, 2000). Communities are effective instruments of governing because they are societal spaces, through which the behaviour of people can be controlled without restricting individual freedom by legislation or official acts (Rose, 1999). 
In rural context, local communities are closely related to concepts of space and place. In addition to a community, places and locality have also been used as governing instruments that emphasize identity, values and social networks (Joseph, 2002, p. 147). According to Fischer (2006, p. 20), culture is the moral texture, and the glue by means of which people engage themselves to cherish and develop places which makes it also a part of governing citizens. A place can be not only a mediator but also an outcome of active citizenship (Kearns, 1995), which emphasizes villages as places constructed through the activeness of rural communities. The commitment to a certain place is the ethical content of selfdetermination, and in rural communities it is constructed through the shared meanings and values related to the village. Even if village associations are local communities constructed through development practices, the moral bond to the home village is the essential factor that makes individuals members of active communities.

The transfer of responsibility from the state to individuals and communities does not mean that the members of the communities are freer to choose how to organize their community life. The concept of self-governing emphasizes that, in a liberal democracy, subjects adopt the rationality of governing as their own 'project' - as norms, values and truths in relation to which they conduct their lives (IbarraColado et al., 2006). Moral subject is considered 'free', but the freedom means conducting her own behaviour in an ethical way, in relation to the prevailing norms (Rose, 1999). The rationality of governing in rural community development means the ways of reasoning that define how villages and rural communities are seen; the norms that define in which way they should progress. For Finnish villages, activeness is the ideal situation, 'an active village' is a synonym for viable and desirable rural community also in the everyday speech of rural people (Kumpulainen, 2012). It reflects how the rationality of active citizenship has become widely accepted norm in rural communities.

The governing works effectively only when the policy level definitions transform local action. Even if rural policy and national village action programmes define rural communities as responsible subjects, active citizenship politics works only if local people change their action towards the policy objectives. Usually, establishment of a village association and the activation of development work do not start until the local people feel that the living conditions and the sense of community are in decline in their village. The founding of a village association is the available model for rural communities offering a chance to cease the local negative progress. The essential way to promote communities to practice development work according to the rural policy is by project funding. Since most of the funding of the local village development projects comes from the European Union's LEADER programme, it means that the projects have to be in accordance with the rural policy objectives. Development work in rural communities is never 
purely self-motivated or arising only from local needs, but it is controlled by the prevailing rationalities, norms and objectives of the rural policy (Kumpulainen, 2012).

\section{Methodology and data}

Every three village associations in the study are a winner in the regional Village of the Year competition (Huikko 2005, Kyynämöinen 2006, and Ylä-Muuratjärvi 2007). I chose to collect my data from the villages, which have gained success in the competition, as I was especially interested in how 'active' communities are represented in the local discourse. I aimed to study of which elements the selfrepresentations of active community consist and how these representations relate to the active citizenship politics promoted by the rural policy. I interviewed all the present and previous chairmen of three winner village associations in the province of Central Finland (except one who refused to be interviewed) in 2007-2008 (twelve interviews). To explain the construction of active rural communities, I applied discourse analysis that emphasizes the role of language in the construction of reality (Norrick, 2001). Discourses and representations are action (Phillips and Hardy, 2002), and they are the essential element in constructing subjectivity (Weedon, 1987, p. 33; Fairclough, 2003; Harman, 2012). When people talk about their villages and their activeness, they give diverse meanings to their local community activities and also produce their identity as an active community.

The Village of the Year competition is managed by the national and the provincial village action organizations. The objective of the competition is to gain visibility to the village action movement and to spread the norms of rural community development by presenting active villages through the competition. The Village of the Year has been chosen in Finland since 1985, and the number of winning criteria has increased especially in the 2000s. The increase of the requirements for 'good' village action is related to the integration of village action movement and the Finnish rural policy (Kumpulainen, 2008). A rewarded village, for example, has to have development projects, take responsibility of local services, market village events and create jobs and find new residents to the village. The awarded villages are model students of village action norms, which make them also implementers of the Finnish rural policy objectives.

Most of the rural communities in Finland find the criteria of the Village of the Year competition so challenging that they do not participate in the competition. This means that the data of the study are collected from the minority of rural communities, from the 'ideal' villages, and the results cannot be generalized to the construction of all kind of rural communities. However, in rural areas the norms of village action have become a widely accepted way of developing local communities and of valuing rural community activities (Kumpulainen, 2012). The 
village action discourse can thus be defined as a hegemonic discourse (van Dijk, 2001), which means that the norms and the representations of village action are widely recognized and used as the way to explain the characteristics, the problems and the development of Finnish rural communities.

I chose to interview the chairmen of the village associations, as I wanted to interview the most active persons in the rural communities, and especially those who also activate other community members. The chairmen of village associations usually are competent project leaders, and often also active and influential persons in other fields of the society. Their speech is only the voice of a few active members of the community; it does not represent the voice of the whole village, even if it often manifests itself as such. An interview is a particular situation of communication with certain implications (Gumperz, 2001), and the chairmen are conscious of their role as presenting their village to the researcher. This kind of a situation easily leads the interviewees to overemphasize, for example, the activeness of their community, and live something out of their representations.

Most of the people living in the villages are members of village associations, but all of them are not involved in community life as actively as the most active individuals. Village celebrations attract most of the villagers, but, for example, in renovating projects the amount of participants is much smaller. A chairman of a village association is not a desired position because of the large amount of responsibility and voluntary work, for which the few most active members of communities usually recycle the position between themselves. In village associations' activities, the division of labour between the genders is quite traditional (women do usually most of the cooking, baking and cleaning and men correspondingly most of the construction and renovation work), and it was also reflected in the composition of the interviewees. Only three out of the twelve interviewed chairmen were women.

The interviews were informal discussions lasting from one to three hours, and constructed around a number of particular themes (history, development projects, future scenarios, organizing of activities, community spirit, relation to the rural policy, challenges and difficulties in community action). In this article, I do not study the representations according to the themes but concentrate only on the discursive construction of activeness.

\section{Results}

People give meaning to their lives and interpret them through narratives, Narratives are also an essential part of creating communities (Johnstone, 2001). It is always a choice of how people talk about their community; where its history starts and what are the main turning points in its development. When members of the rural communities talk about the development of their village, they also 
construct it by choosing certain elements into their story and leaving something out from the picture. The village action discourse presents a particular development story of rural communities, which starts from the decreasing of inhabitants and services and proceeds to the point when local people get activated and start to save their village from the dying of the village scenario (Kumpulainen, 2012). In the active rural communities, there is often a hero story to tell, starting from the decline and ending to the positive future accomplished by active community development.

The narratives of the development in the three rural communities in the study have been quite similar. The villages started to loose inhabitants and local services since 1960 s, and in 1980s-1990s, the local people saw village action as an opportunity to build a new kind of communal life and progress to the declining villages. As in most of active Finnish villages, the village action started in the studied villages first by establishing informal village committees to organize local activities. Later, when applying for European Union project funding, the committees were registered as village associations and the action became more official in character. The village association in Huikko was registered in 1993, in Kyynämöinen 1998 and in Ylä-Muuratjärvi 2002.

\section{The construction of activeness discourse}

The role of the state and the municipality in producing services in rural areas is diminishing, and the active villages try to fill the gaps left by this in the local living conditions. The studied village associations have renovated village halls by European Union project funding, and they maintain them as site for village festivities and shared activities. They also take care of and clean up sports facilities, recreation grounds and the public environment. Village halls also offer facilities for private entrepreneurs and municipality and non-governmental organizations to provide services for local people, such as clubs for children and elderly people. In Ylä-Muuratjärvi, there has also been a project that employed local long-term unemployed persons to provide home care services, targeted especially to the elderly people living in the area. The increasing role of rural communities in service production has also prompted criticism:

I somehow find it strange that we give up to those whose job it would be to provide a service, and we do it on their behalf. It should rather be that we need something and you should do it. (Interviewee 9)

Despite the opposition, the decrease of services concretely activates rural communities, and it also makes local people to adapt responsible subjectivity as a community. The chairmen of village associations produce a village association as an active community in their speech. The term 'active' is repeated, especially when they aim to construct a positive image of the local action. 
If a village is active, it is a sign that things are being done right there, and a goal has been found for which people want to work for. Something that is seen as important.' (Interviewee 11)

'Development' is an indicator for evaluating activeness, especially how the development and change has been achieved by the communities' own action. Activeness is represented as a process with a clear objective, and it is often the result of a few people's activation work that requires 'traditional' rural methods.

The village activism, which grew gradually over the years. This activism has to be milked, then, it kind of just clicks. For some there are many new, mostly people new in the area, but they do also have some of the old folk involved. (Interviewee 12)

The term 'milking' reflects how traditional discourses related to farming still exist in the local representations. The activating of villagers to participate in projects and in community practices is described as a difficult process to leaders.

When villagers get an idea and want to start develop, it is a goddamned job to get voluntary workers to become inspired. It is your own example and activeness. (Interviewee 1)

The activeness discourse often enlarges its object, it constructs the image that the whole community, and often also the whole region, is active, leaving the narratives of passivity and non-participation out of the story. The activeness discourse is not formed only from sentences or phrases where the active word is mentioned but also from other collocations and discourses, through which the local activeness is described. In addition to farming discourse, there are other traditional utterances. In the Finnish peasant lifestyle and mentality, there has been a strong emphasis on hard work, and it is still living strongly in rural community development discourse.

The activation of villagers into projects. People have really rolled their sleeves up, there's new blood and ideas and it's going forward in a whole new way. The activity has really increased. (Interviewee 12)

The development of a village is achieved through the hard work discourse. Nothing happens by itself; everything must be gained through guts and hard work. But only hard work is not enough, there has to be also spirit to fight. The 'fighting' discourse is emphasized especially in the saving projects of village schools.

And now that the village school has been closed then of course it has affected the spirit quite a lot, I should think. When the village has fought to keep the school, and then the negative decision has come, and then the village has still managed to 
rise up and become active, then I think that is a great thing. (Interviewee 11)

Shared 'battles' drive the village forward, and even after 'defeats' you 'cannot stay still', you have 'to rise up' again. Especially when talking about village schools, the municipality is the concrete opponent that makes the decisions to shut down village schools, and it can also be constructed even as the 'enemy' or the party to fight against. Mostly, the opposite party of the fights is not clearly named, which emphasizes the role of a rural community in the development and the future of villages. A municipality does not fight to 'kill' the villages. It is more a passive party, which just lets things happen, but a village association is represented as the active party or subject of the battle. Through the hard work and the fighting discourses, rural communities are constructed as persevering subjects, which produce moral ground for becoming active and responsible for the villages development.

Different and also contradictory discourses live in the interviewees' speech. The activeness discourse produces and reproduces a village not only as a traditional rural place but also as a modern developing place. The active rural community is the result of conscious strategic development activities, which is reflected in the speech as strategic development discourse. However, there are also elements from the local history, identity and regionalism, which are specific, constructed through the particular place and culture. Considered from the Foucaultian perspective, it is a part of the objectification and mobilization of local tradition and culture (Barnett, 2001, p. 19; Ibarra-Colado et al., 2006).

\section{A village as a process}

When the chairmen talk about 'us' or from their community, it is not clear if they talk about the village association or all the people living in the village. However, the objective of discourse analysis is not to bring out the distinctions between diverse concepts but to emphasize the multiform nature of representations in constructing reality (Fairclough, 2003). In the speech of interviewees a village is conceptualized as an object, a subject, an instrument and especially as a process.

When a village is the focus of action or an object, people do things on its behalf. The village is a beloved place, which has absolute value. It means that people are willing to work for the best of it without counting sacrifices or working hours. The village is nurtured and cherished, to get it to succeed and flourish.

It is partly tradition but I guess it is also partly ambition for the village you are working for, to try and keep the village alive and thriving. (Interviewee 4)

The task of community development is to keep the village alive and on its feet. A village is constructed more like a living organism, rather than a technical, 
governmental or structural region in a map. It emphasizes the moral obligation to look after and to become responsible for the village. In the same way as a community binds its members by its norms, values and meanings (Rose, 1999, p. 172-173), also the emotional bond to the village constructs the local moral texture. In the interviewees' speech a village is also represented as an acting subject.

And if the village has a particular issue. (Interviewee 4)

The construction of a place as an object or as a subject affects whether it can be considered as a responsible agent for its development. When a village is an object, the responsible actor is someone else, such as villagers or a village association. When a village is represented as a subject, the particular interests of different groups are manifested as the voice of the whole village, which means that the distinction between a community and a place is blurred. A village is represented as an actor and the actors producing the village are covered. A village is also constructed as an instrument to gain other objectives.

And often a village like this is a small community in quantity as well. It is not about thousands or even hundreds of people - sometimes it is only a case of tens of people. This makes you want to do your part. (Interviewee 11)

A small-size community activates people effectively. Everyone knows each other, which increases the willingness and heightens the moral obligation to get involved. The sense of place and local identity bind people morally to take responsibility of their region. Taking care of the village hall, shared places and environment is felt as nurturing their 'own' places. A village and a community are instruments that produce active citizenship (e.g. Rose, 2000) through the emotional bond to the place (Kearns, 1995).

A village is constructed especially as a process, a constantly changing place (Massey, 2005, p. 9). A change can be either development for better or regressing for worse, which means losing inhabitants, closing down the village school and especially fear that the village will 'die'. A village is never still; it 'rises', 'decreases', 'develops', 'declines', 'recovers', 'fades', 'comes alive' or 'dies'. A village as a process requires action. There is a risk that 'life' in a village can 'fade away'. Immobility is not enough; a village must be constantly 'pushed forward'.

If you start slacking even a little, then it does start to diminish and fade out. (Interviewee 2)

But when the school closed down, it was a blow to the village. On the other hand, it has lit a spark in that the school has been left available for use by the villagers as a space for various activities, which has opened up new possibilities and will maybe lead to a new rise. It is interesting to see the effect of being chosen Village 
of the year. I've noticed that people who hadn't attended before are now finding their way to the village hall, so maybe it does mean a new rise. (Interviewee 9)

A village is an undulating process, where ups and downs fluctuate. The next rise, which means future and positive development, does not come without work; it has to be made by community development activities. The wider societal development, surrounding reality, and its threats are constantly a part of local consciousness and the definitions of the places.

The universal development of the society is often represented as a process that is like a force of nature: the development supposedly cannot be governed, and the actors behind the movement are blurred. At the same time, there is an emphasis on local opportunities to change development, which means that the global movement can be stopped by local fighting. A village is not represented like a force of nature that lives by itself but an object to act for. A village is a process, which requires active actors 'to set the wheels in motion', the producers of places and local communities. The process and object nature of a village are emphasized at the same time, and it is manifested outside as a developing and active community.

When constructing a village as a process, speakers also represent it as a developing - or non-developing - space. The aspiration after development can be considered as political and concrete strategies, but it is also a system of representation (Escobar, 1995; Kothari, 2007, p. 130), which defines a village association as the community, which makes the local change. In defining the village as a process through the development discourse, also global consciousness becomes a part of the local self-definition and the sense of a village. People evaluate themselves related to wider societal development. How have they succeeded in keeping track of it? And by doing that, the speakers also construct their own responsibility for the local development.

\section{Active communities as rural policy implementers}

Local self-representations are based on the development discourse, and the chairmen of the village associations have adopted responsible subjectivity, according to the ideology of active citizenship politics. Active rural communities can be defined as rural policy implementers, but it does not mean that they have adopted all the policy objectives offered from above. The interviewed chairmen had not read any national village action programmes, and they were not interested in rural policy - they were interested only in their own village's development. The construction of active citizens is not so much about commitment to a certain ideology, but it is based on the construction of responsible and moral subjects and at the local level.

The national village action programmes are a part of rural policy, and they 
construct the rationality of rural community development. The objectives of rural community development are constructed explicitly according to the ideology of active citizenship. It is also reflected on how the state is represented. In the narrative of the development of rural areas, the build-up of the strong public sector is represented as unnatural process (Kumpulainen, 2012). Correspondingly, the prevailing development, where state's and municipalities' responsibilities are transformed to individual citizens and to local communities, is constructed as natural situation, as going back to the state where people and communities take care of each other without the bureaucratic public sector. It is a romanticized representation of the history before welfare state and it underestimates the role of state policy in the progress of rural areas in Finland.

In the second national village action programme (2003-2007), there is a list of village action values that are more reflections of the policy norms than actual local values. Locality, communality, individuality, entrepreneurship, equality, participatory democracy, the ideal of independence and single-family housing ( $p$. 70) are represented as values of Finnish village associations. The emphasis on entrepreneurship is a political choice that complies with the principles of active citizenship politics (Dean and Hindess, 1998, p. 102).

In this position you don't act like a claimant, but rather as an entrepreneur (the second national village action programme, p. 47).

According to the programmes, local actors should not complain about the difficulties but practice local risk management (Rose, 1999, p. 164) in facing them: evaluate all the possibilities and challenges in their community and then make use of the local strengths in developing their village. The equality is defined in the second national village action programme as related to the entrepreneurial attitude. It is seen as the 'equality of opportunity', which is widely adopted ideological vision in right-wing parties in Finland. However, the programme does not list which kind of opportunities there should be for rural communities but stresses the duties of rural communities in exploiting them.

Even if the governing works effectively and the rural communities have adopted the active subjectivity, there are also contradictions between local and policy level discourses. In the local representations, the fighting and hard work discourses reveal more complicated story about developing rural communities. They reflect the difficulties and contradictions in community development, and they draw a more critical picture of the activeness than the representations in the national village action programmes. The activation of Finnish villages is not a natural process but a struggle for surviving. The interviewed chairmen are active citizens by taking responsibility of their village, but they have not adopted the entrepreneurial subjectivity. 


\section{Conclusions}

In this article, I have studied active rural communities in Finland. They are the model students of active citizenship taking responsibility of their villages' development. I have been searching for an answer to the question of how active rural communities are constructed in local discourse. The leaders of active communities have adopted the development and the activeness discourse as the way to define themselves and their communities. In the speech of the village associations' chairmen, a village is constructed especially as a nurtured process, which progresses and develops according to the amount of local people's commitment to their community and home village. The moral and emotional bond to the place is the glue which gets individuals to become active members of the community. The analysis of the speech of the village association chairmen shows that the representation of an active community is a mixture of the traditional rural and the strategic community development discourses.

According to Finnish rural policy, if people want to save their villages, participation and community-led development are represented as the only way to achieve it, and the passiveness of local individuals is constructed as the obstacle for development. The entrepreneurial discourse in rural policy discourse defines local problems as the result of local passiveness and non- participation, not a structural or a policy problem. It constructs the decline of rural regions as their own choice. Even if the leaders of active communities have adopted the strategic development discourse as the way to define their villages, the rural policy objective to get rural communities to adopt entrepreneurial subjectivity has not been achieved. Instead, the local discourse reflects how the local activeness is more about struggling for survival. The members of rural communities do not act because they think as entrepreneurs but because they feel that they do not have any other options to save their village.

\section{References}

Barnett, C. (2001) Culture, geography, and the arts of government, Environment and Planning D: Society and Space, 19 (1), 7-24.

Blakeley, G. (2010) Governing ourselves: citizen participation and governance in Barcelona and Manchester, International Journal of Urban and Regional Research, 34 (1), 130-145.

Cruikshank, B. (1996) Revolutions within: self-government and self-esteem, in A. Barry, ed., Foucault and Political Reason. Liberalism, Neo-liberalism and Rationalities of Government, Routledge, London and New York, pp. 231-252.

Dean, M. (1999) Governmentality. Power and Rule in Modern Society, Sage, London. 
Dean, M. and Hindess, B. (1998) Governing Australia. Studies in Contemporary

Rationalities of Government, University Press, Cambridge.

Escobar, A. (1995) Encountering Development. The Making and Unmaking of the Third World, Princeton University Press, New Jersey.

Eversole, R. (2010) Remaking participation: challenges for community development practice, Community Development Journal, 47 (1), 29-41.

Fairclough, N. (2003) Analysing discourse. Textual analysis for social research, Routledge, London.

Fischer, F. (2006) Participatory governance as deliberative empowerment. The cultural politics of discursive space, The American Review of Public Administration, 36 (1), 1940 .

Foucault, M. (1981) The History of Sexuality: Volume 1, An Introduction, Penguin, Harmondsworth.

Foucault, M. (2002) Essential Works of Foucault 1954-1984, Volume 3, Power, Penguin, London.

Gaynor, N. (2011) In-active citizenship and the depoliticization of community development in Ireland, Community Development Journal, 46 (1), 27-41.

Gumperz, J. J. (2001) Interactional socioliguistics: a personal perspective, in D. Schiffrin, D. Tannen \& H. E. Hamilton, eds, (2011) The Handbook of Discourse Analysis, Blackwell Publishers, Malden, pp. 215-228.

Harman, K. (2012) Everyday learning in a public sector workplace: the embodiment of managerial discourses, Management Learning, 43 (3), 275-289.

Herbert-Cheshire, L. \& Higgins, V. (2004) From risky to responsible: expert knowledge and the governing of community-led rural development, Journal of Rural Studies, 20 (3), 289-302.

Hyyryläinen, T. (2000) Kylätoiminnan perinne sosiaalisena pääomana, in Hyyryläinen and Rannikko, toim, Eurooppalaistuva maaseutupolitiikka. Paikalliset toimintaryhmät

maaseudun kehittäjinä, Vastapaino, Tampere, pp. 109-119.

Ibarra-Colado, E., Clegg, S. R., Rhodes, C. \& Kornberger, M. (2006) The ethics of managerial subjectivity, Journal of Business Ethics, 64 (1), 45-55.

Johnstone, B. (2001) Discourse analysis and narrative, in D. Schiffrin, D. Tannen and H. E. Hamilton, eds, (2011) The Handbook of Discourse Analysis, Blackwell Publishers, Malden, pp. 635-649. 
Joseph, M. (2002) Against the Romance of Community, University of Minnesota Press, Minneapolis.

Kearns, A. J. (1992) Active citizenship and urban governance, Transactions of the Institute of British Geographers, New Series, 17 (1) 20-34.

Kearns, A. J. (1995) Active citizenship and local governance: political and geographical dimension, Political Geography, 14 (2), 155-175.

Kothari, U. (2007) Power, knowledge and social control in participatory development, in B. Cooke and U. Kothari, eds, (2007) Participation: The New Tyranny?, Zed Books, London, pp. 139-152.

Kotkas, T. (2010) Governing health and social security in the twenty-first century: active citizenship through the right to participate, Law Critique, 21 (2), 163-182.

Krawchenko, T. (2014) Bringing municipalities into rural community and economic development: Cases from Atlantic Canada, The Journal of Rural and Community Development, 9 (3), 78-96.

Kumpulainen, K. (2008) Mistä on Vuoden Kylät tehty? Maaseudun Uusi Aika, 16 (2), $44-58$.

Kumpulainen, K. (2012) Kylätoiminta ja aktiivisen kylän tuottaminen, University of Jyväskylä, Jyväskylä.

Marinetto, M. (2003) Who wants to be an active citizen? The politics and practice of community involvement, Sociology, 37 (1), 103-120.

Massey, D. (2005) For Space, SAGE, London.

Norrick, N. R. (2001) Discourse and semantics, in D. Schiffrin, D. Tannen and H. E. Hamilton, eds, (2011) The Handbook of Discourse Analysis, Blackwell Publishers, Malden, pp. 76-99.

Phillips, N. and Hardy, C. (2002) Discourse analysis: investigating processes of social construction, SAGE, London.

Rabinow, P. (1991) The Foucault Reader: An Introduction to Foucault's Thought, Penguin, London.

Ray, C. (2000) The EU LEADER programme: Rural Development Laboratory, Sociologia Ruralis, 40 (2), 163-171.

Rose, N. (1999) Powers of freedom. Reframing political thought, University Press, Cambridge.

Rose, N. (2000) Community, citizenship, and the third way, American Behavioral 
Scientist, 43 (9), 1395-1411.

Triantafillou, P. and Nielsen, M. R. (2001) Policy empowerment: the making of capable subjects, History of Human Sciences, 14 (2), 63-86.

van Dijk, T. A. (2001) Critical discourse analysis, in D. Schiffrin, D. Tannen and H. E. Hamilton, eds, (2011) The Handbook of Discourse Analysis, Blackwell Publishers, Malden, 352-371.

Weedon, C. (1987) Feminist Practice and Poststructuralist Theory, Oxford, Blackwell.

Williams, G. (2004) Evaluating participatory development: tyranny, power and (re)politicisation, Third World Quarterly, 25 (3), 557-578. 